\title{
Mass Cytometry Study on the Heterogeneity in Cellular Association and Cytotoxicity of Silver Nanoparticles in Human Immune Cells
}

\author{
My Kieu Ha ${ }^{\mathrm{a}, \mathrm{b}}$, Jang-Sik Choi ${ }^{\mathrm{a}, \mathrm{b}}$, Zayakhuu Gerelkhuu ${ }^{\mathrm{a}, \mathrm{b}}$, Sook Jin Kwon ${ }^{\mathrm{a}, \mathrm{b}}$, \\ Jaewoo Song ${ }^{\mathrm{c}}$, Yangsoon Lee ${ }^{\mathrm{a}, \mathrm{d}}$, Yeoung-Eun Kim ${ }^{\mathrm{a}, \mathrm{d}}$ and Tae Hyun
} Yoon $^{\mathrm{a}, \mathrm{b}^{*}}$

${ }^{a}$ Center for Next Generation Cytometry, Hanyang University, Seoul 04763, Republic of Korea

${ }^{b}$ Department of Chemistry, College of Natural Sciences, Hanyang University, Seoul 04763, Republic of Korea

${ }^{c}$ Department of Laboratory Medicine, College of Medicine, Yonsei University, Seoul 03722, Republic of Korea

${ }^{d}$ Department of Laboratory Medicine, College of Medicine, Hanyang University, Seoul 04763, Republic of Korea

*Corresponding author: taeyoon@hanyang.ac.kr (Tae Hyun Yoon)

\begin{abstract}
There have been many reports about the adverse effects of nanoparticles (NPs) on the environment and human health. Conventional toxicity assessments of NPs frequently assume uniform distribution of monodisperse NPs in homogeneous cell populations, and provide information on the relationships between the administered dose of NPs and cellular responses averaged for a large number of cells. They may have limitations in describing the wide heterogeneity of cell-NP interactions, caused by cell-to-cell and NPto-NP variances. To achieve more detailed insight into the heterogeneity of cell-NP interactions, it is essential to understand the cellular association and adverse effects of NPs at single-cell level. In this study, we applied mass cytometry to investigate the interactions between silver nanoparticles (AgNPs) and primary human immune cells. High dimensionality of mass cytometry allowed us to identify various immune cell types
\end{abstract}


and observe the cellular association and toxicity of AgNPs in each population. Our findings showed that AgNPs had higher affinity with phagocytic cells like monocytes and dendritic cells and caused more severe toxic effects than with T cells, B cells and NK cells. Multi-element detection capability of mass cytometry also enabled us to simultaneously monitor cellular AgNP dose and intracellular signaling of individual cells, and subsequently investigate the dose-response relationships of each immune population at single-cell level, which are often hidden in conventional toxicity assays at bulk-cell level. Our study will assist future development of single-cell dose-response models for various NPs and will provide key information for the safe use of nanomaterials for biomedical applications.

Keywords: silver nanoparticles; mass cytometry; single cell; immunotoxicity; cellular uptake

\section{Introduction}

As nanoparticles (NPs) have increasingly been employed in various consumer products and biomedical applications, their potential toxicity has become a public concern, since there have been many reports on the adverse effects of NPs on the environment and human health (Colvin 2003, Nel et al. 2006, Ray et al. 2009). It is important to examine the potential hazards of NPs on biological systems, especially on human immunity, which consists of various cell populations responsible for protecting our body from infections and malignancies. Conventional assays in nanotoxicity studies analyze the relationship between the administered dose of NPs and cellular responses, which are often averaged over a large number of cells. These assays at bulk-cell level may not able to describe cell-to-cell and NP-to-NP variances of cell-NP interactions under in vivo conditions (Singh et al. 2014). Knowledge of the biodistribution and toxicity of 
NPs in individual cells is essential for studying the dose-response relationship at a single-cell level and for gaining a more detailed understanding of cell-NP interactions.

To date, the biodistribution and toxicity of NPs in single cells have received noticeable attention but are mostly studied separately with only a few studies reporting on the single-cell dose-response relationship. On the one hand, a variety of quantitative and semiquantitative approaches have been employed to address the variability in the cellular uptake of NPs. Electron microscopy with a nanoscale resolution is suitable for examining the cellular localization of electron-dense NPs, but suffers from lowthroughput and does not allow for the analysis of dynamic biological processes (Ivask, Mitchell, Malysheva, et al. 2017). Inductively coupled plasma mass spectrometry (ICPMS) has been used to quantify the total metal concentration in a large number of cells after acid digestion, which is then averaged over the entire cell population to estimate the cellular NP content (Merrifield et al. 2018). This measurement can provide integrated information from thousands of cells, but will mask the stochastic diversity of individual cellular NP uptake (Meyer et al. 2018). New applications of ICP-MS based techniques have allowed for the single-cell quantification of cellular NP amounts. Laser ablation ICP-MS (LA-ICP-MS) enables the quantification of metal content in single cells with additional insights into subcellular localization. However, this image-based method suffers from low throughput and relatively low sensitivity (Yang et al. 2017). Single-particle ICP-MS utilizes a time-resolved mode to enable direct quantification of the concentration, size distribution, and agglomeration state of NPs (Yang et al. 2017). However, since it is not optimized for bioanalysis, it does not distinguish between cellassociated particles and unbound ones, so it should be coupled with other techniques with imaging capability such as LA-ICP-MS to determine the quantity and distribution of cellular NPs. 
On the other hand, several techniques have also been applied to examine the in vitro toxicity of NPs, but few can be used to monitor both the cellular association and toxic effects of NPs simultaneously. Fluorescence-based microscopy is one of the few methods that can perform both tasks simultaneously, but it has low throughput and limited spatial resolution (200 - $500 \mathrm{~nm}$ ) (Vanhecke et al. 2014). Moreover, due to the cross-talk and autofluorescence issues of the fluorophores, it fails to estimate the number of cell-associated NPs quantitatively (Orecchioni et al. 2017). Flow cytometry (FCM) is another technique that can simultaneously monitor cellular NP uptake and cellular responses by measuring the light-scattering and fluorescence-labeling intensities, respectively (Park et al. 2017, Ha et al. 2018). However, for those cells that have wide heterogeneity (e.g., immune cells), FCM is inadequate in providing simultaneous analyses of cell type, activation status, and elevation/depletion of secreted molecules due to its limited number of fluorescence detection channels. Recently, a combination of time-of-flight ICP-MS and FCM was developed and named as mass cytometry (Bandura et al. 2009, Bendall et al. 2011). It enables the detection of various metal-tagged cellular markers based on the mass-to-charge ratio of the elemental isotopes, with minimal overlap and cellular background interference. Current mass cytometry instruments allow up to 50 metal isotope labels (with atomic weights ranging from 75 to 209) to be detected simultaneously at single-cell resolution (Yang et al. 2017). This technique is suitable for a large panel design to analyze the cellular association and toxic effects of NPs in heterogeneous immune cells (Guo et al. 2017, Ivask, Mitchell, Hope, et al. 2017, Orecchioni et al. 2017).

Among the variety of currently available NPs, silver NPs (AgNPs) have been widely used for therapeutic interventions and medical diagnosis as drug carriers, nanoprobes, bio-imaging and labeling agents (Wei et al. 2015). At the same time, 
extensive studies have investigated the involvement of AgNPs in adverse biological effects, such as reactive oxygen species (ROS) generation, mitochondrial injury, DNA damage cell-cycle arrest and apoptosis induction (AshaRani et al. 2009, Ghosh et al. 2012, Martínez-Gutierrez et al. 2012, Ivask et al. 2014). AgNPs can enter the systemic circulation and cause cardiovascular toxicity due to their access to the heart, bloodstream and blood vessels (Takenaka et al. 2001, Nemmar et al. 2002). They have been found to exert toxicity on peripheral blood mononuclear cells (PBMCs), induce aggregation in platelets and promote procoagulant activity in red blood cells (Greulich et al. 2011, Jun et al. 2011, Bian et al. 2019).

In this study, we have adapted mass cytometry to investigate the cellular association and toxicity mechanisms of AgNPs in immune cells. Since the cellular association and cytotoxicity of AgNPs may be strongly influenced by the heterogeneous nature of PBMCs as well as the diverse physicochemical properties and colloidal behaviors of NPs, we have studied the impact of various cell types of PBMCs on the cellular association of AgNP, which led to even greater variances in signaling activities and apoptosis levels of individual cells with different phenotypes. Our findings will be useful in developing a single-cell dose-response model for future nanotoxicity studies based on the mass cytometry technique and will also provide information for the appropriate utilization of nanomaterials, especially AgNPs, in commercial and biomedical applications.

\section{Materials and methods}

\section{Silver nanoparticles (AgNPs)}

The AgNPs used in this study were BioPure Silver Nanospheres (nanoComposix, USA) with a polyvinylpyrrolidone coating and nominal core diameters of 10 and $20 \mathrm{~nm}$ 
(denoted ${ }^{\mathrm{PVP}} \mathrm{Ag}^{10}$ and ${ }^{\mathrm{PVP}} \mathrm{Ag}^{20}$, respectively).

\section{Isolation of peripheral blood mononuclear cells (PBMCs) from human whole}

\section{blood}

Whole blood was drawn from healthy donors into EDTA-treated tubes (BD Vacutainer®, USA), and PBMCs were isolated from whole blood via density gradient centrifugation using Ficoll-Paque PLUS (GE Healthcare Bio-Sciences, Sweden). Briefly, blood was diluted 1:1 with Dulbecco's phosphate-buffered saline (DPBS, Welgene, Korea), and the diluted blood was overlaid on the Ficoll reagent in centrifuge tubes. These tubes were centrifuged at $400 \times g$, at room temperature for 40 minutes on a centrifuge with a swing-bucket rotor (model 1248R, Labogene, Korea). The mononuclear layer was then collected and transferred to a new tube, washed in DPBS, and pelleted by centrifugation at $200 \times g$, at room temperature for 10 minutes. The resulting supernatant was discarded, and the cells were resuspended in RPMI-1640 medium (Lonza ${ }^{\mathrm{TM}}$ BioWhittaker ${ }^{\mathrm{TM}}$, USA) supplemented with $10 \%$ fetal bovine serum (Gibco, USA) and 1\% penicillin/streptomycin (Gibco, USA). Cell suspensions were transferred to $35 \times 10 \mathrm{~mm}$ petri dishes (SPL Life Sciences, Korea) for subsequent treatment with AgNPs.

\section{Sample preparation for mass cytometry measurements}

Cells were incubated with 2 or $5 \mu \mathrm{g} / \mathrm{mL}$ of ${ }^{\mathrm{PVP}} \mathrm{Ag}^{10}$ or ${ }^{\mathrm{PVP}} \mathrm{Ag}^{20} \mathrm{NPs}$ in RPMI complete media for $3 \mathrm{~h}$ at $37^{\circ} \mathrm{C}$ and $5 \% \mathrm{CO}_{2}$. Then, cells were labelled with surface and intracellular markers according to the Maxpar Phosphoprotein Staining with Fresh Fix Protocol (Fluidigm Corp., USA). Briefly, cells were washed with DPBS to remove excess AgNPs and then stained with Cisplatin for viability. After that, cells were stained with surface antibodies (Table 1). After surface staining, cells were fixed in $1.6 \%$ 
formaldehyde and permeabilized with ice-cold methanol. Then, cells were stained with phosphoprotein antibodies (Table 1). After intracellular staining, cells were incubated with Cell-ID Intercalator-Ir solution overnight. Prior to data acquisition, cells were washed and suspended at $1 \times 10^{6}$ cells $/ \mathrm{mL}$ in ultrapure water. Calibration beads were added $1: 10 \mathrm{v} / \mathrm{v}$ for later normalization. Cells were then filtered into strainer cap tubes and ready for acquisition.

\section{Data acquisition and analysis}

The samples were analyzed on the Helios mass cytometry platform (Fluidigm Corp., USA) at a flow rate of $45 \mu \mathrm{L} / \mathrm{min}$, in dual instrument mode with noise reduction turned on, and with 'on the fly' processing. Measurements were performed in triplicate. The initial raw data were processed into standard FCS format and normalized by the CyTOF software version 6.5.358 (Fluidigm Corp., USA).

FlowJo (FlowJo, LLC, USA) and Cytobank (Cytobank, Inc., USA) were used for data gating and visualization. Inverse hyperbolic sine (arcsinh) transformation was applied to the raw data. The major immune cell subsets were then gated using the 12 surface markers (Table 1). The gating pipeline is presented in Figure S1. The SPADE (spanning tree progression analysis of density-normalized events) clustering algorithm was used to reduce the dimensionality of the data. From the SPADE plots, we identified the cell subsets that had high cellular AgNP uptake and cell death levels based on the intensities of ${ }^{107} \mathrm{Ag}$ and ${ }^{195} \mathrm{Pt}$. Next, the median expression levels of 9 phosphoprotein markers (Table 1) were plotted on heatmaps in order to understand the signaling pathways of AgNP-induced toxicity. Then, the t-distributed stochastic neighbor embedding (t-SNE) dimension-reduction method was used to visualize single-cell resolution of the data. The bivariate plots between cellular responses and AgNP uptake 
were used to analyze the dose-response relationship at a single-cell level.

Quantification of cellular AgNP uptake was done using $\mathrm{Ag}^{+}$ion calibration, in which a standard $\mathrm{Ag}^{+}$ion solution diluted in $5 \% \mathrm{HNO}_{3}$ was analyzed in "solution mode". The transmission efficiency (TE) of a given number of ${ }^{107} \mathrm{Ag}$ atoms was determined as in equations 1 and 2 (Tricot et al. 2015).

$$
\begin{gathered}
\operatorname{exp~counts~}_{107 \mathrm{Ag}}=\frac{\mathrm{C}_{\mathrm{Ag}}}{\mathrm{M}_{\mathrm{Ag}}} \times \frac{\% \mathrm{NA}_{107 \mathrm{Ag}}}{100} \times \mathrm{N}_{\mathrm{a}} \times \mathrm{I} \\
\mathrm{TE}=\frac{\text { obs counts }_{107 \mathrm{Ag}}}{\text { exp counts }} \text { enf }_{10 \mathrm{Ag}}
\end{gathered}
$$

where $\mathrm{C}_{\mathrm{Ag}}$ and obs counts $107 \mathrm{Ag}$ are the concentration $(\mu \mathrm{g} / \mathrm{mL})$ and observed ${ }^{107} \mathrm{Ag}$ counts from the standard $\mathrm{Ag}^{+}$ion solution, $\mathrm{M}_{\mathrm{Ag}}$ is the atomic mass of $\mathrm{Ag}, \% \mathrm{NA}_{107 \mathrm{Ag}}$ is the natural abundance percentage of ${ }^{107} \mathrm{Ag}(51.839 \%), \mathrm{N}_{\mathrm{a}}$ is Avogadro's number $(6.02 \times$ $10^{23}$ ), and I is the injection speed (or flow rate).

Cell samples were analyzed in "event mode" and their expected cell-associated ${ }^{107} \mathrm{Ag}$ signal (exp cell $\mathrm{1}_{107 \mathrm{Ag}}$ ) was calculated from the observed ${ }^{107} \mathrm{Ag}$ signal (obs cell $107 \mathrm{Ag}$ ) and TE as shown in equation 3 . Then, the particle mass and number of cell-associated Ag could be calculated using equation 4 (Ivask, Mitchell, Hope, et al. 2017).

$$
\begin{gathered}
\text { exp cell } \text { ce7Ag }_{107}=\frac{\text { obs cell }_{107 \mathrm{Ag}}}{\mathrm{TE}} \\
\text { cell } \mathrm{m}_{\mathrm{Ag}}=\operatorname{exp~cell~}_{107 \mathrm{Ag}} \times \frac{100}{\% \mathrm{NA}_{107 \mathrm{Ag}}} \times \frac{1}{\mathrm{~N}_{\mathrm{a}}} \times \mathrm{M}_{\mathrm{Ag}}
\end{gathered}
$$

\section{Results}

\section{Cellular uptake of AgNPs}

To identify the major immune cell subsets, we applied the SPADE clustering algorithm (Bendall et al. 2011) to the 12 surface markers (Table 1). This approach uses a minimum-spanning tree algorithm, in which each tree node encompasses a cluster of 
cells that are phenotypically similar in the 12-dimensional space defined by the surface markers, and the connections between nodes display the relationships between the cell clusters. The SPADE trees provide a convenient approach to map complex, highdimensional data into a representative two-dimensional structure. The intensity of ${ }^{107} \mathrm{Ag}$ represents the cellular uptake of AgNPs. The SPADE trees show that cellular uptake of AgNPs was not evenly distributed in all populations (Figure 1). The uptake amounts of ${ }^{\mathrm{PVP}} \mathrm{Ag}^{10}$ and ${ }^{\mathrm{PVP}} \mathrm{Ag}^{20} \mathrm{NPs}$ were relatively similar, with that of ${ }^{\mathrm{PVP}} \mathrm{Ag}^{20} \mathrm{NPs}$ (Figure 1B,C,D) being slightly higher than that of ${ }^{\mathrm{PVP}} \mathrm{Ag}^{10} \mathrm{NPs}$ (Figure 1E,F,G). The 2 types of AgNPs only had subtle difference in cellular uptake amounts because the difference in their sizes was relatively small (only 2 fold). Among the identified populations, monocytes and dendritic cells generally had higher AgNP uptake amounts than other cell types. Because they are phagocytic cells, monocytes and dendritic cells have a higher tendency to ingest foreign particles than other non-phagocytic cells (Zolnik et al. 2010, Luo et al. 2015).

In the samples treated for the same exposure time $(3 \mathrm{~h})$ but with different doses of $\operatorname{AgNP}(2$ vs. $5 \mu \mathrm{g} / \mathrm{mL}$ ) (Figure 1B and 1D, Figure 1E and 1G), the cellular AgNP content increased as the administered dose increased. This agrees with our previous study regarding the dose-dependent cellular uptake of AgNPs (Ha et al. 2018). However, when comparing samples treated with the same AgNP dose $(2 \mu \mathrm{g} / \mathrm{mL})$ but for different exposure time (3 vs. 6 h) (Figure 1B and 1C, Figure 1E and 1F), cellular AgNP content decreased as the exposure time increased, most obviously in monocytes and dendritic cells. This observation suggests that after $6 \mathrm{~h}$, the phagocytosed AgNPs were either broken down or excreted, making their cellular dose decrease. 


\section{Cellular response to AgNP exposure}

Figure 2 displays the cell death levels of identified populations after AgNP treatment.

The cell death level is represented by the intensity of cisplatin, which is a molecule that can penetrate late apoptotic and necrotic cells that have lost their membrane integrity.

As shown in Figure 2, the cell death levels were different between populations.

Monocytes and dendritic cells had the highest cell death levels among all identified populations, which corresponded to their high AgNP uptake. Their cell death levels also decreased when the exposure time increased from $3 \mathrm{~h}$ to $6 \mathrm{~h}$ but increased when the administered dose increased from $2 \mu \mathrm{g} / \mathrm{mL}$ to $5 \mu \mathrm{g} / \mathrm{mL}$. The corresponding patterns in cellular AgNP uptake and cell death levels confirmed that the cell death in the identified immune populations was caused by the cellular association and toxic effects of AgNPs.

These observations suggest that a short-exposure at a high dose of AgNPs will result in higher cellular association and eventually higher toxicity compared to longexposure at a low dose, especially in monocytes and dendritic cells. This means that in phagocytic cells like monocytes and dendritic cells, AgNPs can be ingested and cause toxic effects more quickly and efficiently than in other non-phagocytic cells. Therefore, it is important to understand by which signaling pathways the AgNPs exert their toxic effects and induce cell death.

In order to understand the signaling pathways behind AgNP-induced toxicity, we used heatmaps to visualize the median intensity of 9 intracellular protein markers in the identified immune populations. Figure 3 shows that the toxic effects of AgNPs did not alter the expression levels of all 9 signaling proteins, but only those of $\mathrm{I} \kappa \mathrm{B} \alpha$, STAT1, and caspase 7. However, at such low doses of AgNPs (i.e. 2 and $5 \mu \mathrm{g} / \mathrm{mL}$ ), the expression levels of I $\mathrm{B} \alpha$, STAT1, and caspase 7 in T cells, B cells, and NK cells in 
AgNP-treated samples were not significantly different from those of control. Only in monocytes and dendritic cells, the differential expressions of these signaling proteins were found especially significant. Compared to the control, in AgNP-treated samples, I $\mathrm{B} \alpha$ was downregulated while STAT1 and cleaved caspase 7 were upregulated in monocytes and dendritic cells. This finding suggests that exposure to AgNPs led to the activation of contrasting and complex cellular signaling pathways: STAT1 phosphorylation to promote inflammation, NF- $\kappa \mathrm{B}$ signaling (via degradation of $\mathrm{I} \kappa \mathrm{B} \alpha$ ) to prevent apoptosis, and activation of caspase 7 to cleave downstream substrates that can eventually lead to apoptosis. It also indicates that low doses of NPs (in this case, $5 \mu \mathrm{g} / \mathrm{mL}$ or less) may cause weak and chronic adverse effects in the signaling functionality of T cells, B cells, and NK cells, but strong and acute toxicity in monocytes and dendritic cells.

Despite providing simple and easy-to-interpret visualization, SPADE plots and heatmaps do not preserve the single-cell resolution of mass cytometry data. To make a representative visualization of cellular AgNP uptake and cell death as well as the induction of the differentially-expressed signaling proteins (i.e. IкB $\alpha$, STAT1, and caspase 7) with single-cell resolution, we applied the t-SNE dimension reduction method, which is a computational approach for visualization of high-dimensional data with single-cell resolution (Van Der Maaten and Hinton 2008). t-SNE clustered the single cells into populations according to similarities in the multi-dimensional phenotypic expression of 12 surface proteins (Table 1) and projected the clusters onto bi-axial plots, as in Figure 4 (Characterization of each cell type in each sample is presented in Figure S3-S10).

The single-cell resolution obtained with the t-SNE analysis demonstrated heterogeneity in cellular AgNP uptake and the signaling expression profiles of PBMCs 
after AgNP-treatment. t-SNE results supported the cellular AgNP uptake and toxicity data observed in the SPADE plots. These results show that cellular uptake of ${ }^{\mathrm{PVP}} \mathrm{Ag}^{10}$ and ${ }^{\mathrm{PVP}} \mathrm{Ag}^{20} \mathrm{NPs}$ occurred quickly (within $3 \mathrm{~h}$ ) in monocytes and dendritic cells, exerting remarkable toxicity; conversely, uptake was slower in T cells, B cells, and NK cells, and did not cause severe cell death. They also show that AgNP uptake and cell death levels slightly decreased when the exposure duration was extended from $3 \mathrm{~h}$ to $6 \mathrm{~h}$ but increased when the exposure dose increased from $2 \mu \mathrm{g} / \mathrm{mL}$ to $5 \mu \mathrm{g} / \mathrm{mL}$. The

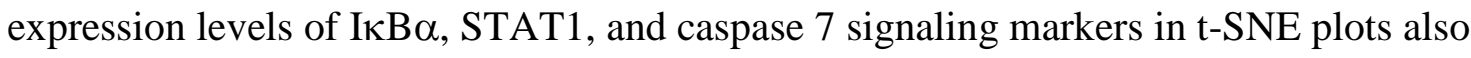
supported the heatmap findings: compared to control cells, I $\kappa \mathrm{B} \alpha$ was downregulated while STAT1 and caspase 7 were upregulated in samples exposed to AgNPs. However, the differential expression levels of $\mathrm{I} \kappa \mathrm{B} \alpha$, STAT1, and caspase 7, as well as AgNP uptake and cell death levels did not vary much between samples treated with ${ }^{\mathrm{PVP}} \mathrm{Ag}^{10}$ and ${ }^{\mathrm{PVP}} \mathrm{Ag}^{20} \mathrm{NPs}$. This indicates that the 2-fold size difference did not cause any notable changes in the toxic effects of these two NPs.

\section{Dose-response relationship at a single-cell level}

Because monocytes and dendritic cells were two populations that showed more significant AgNP uptake and cellular responses than the other cell types, we wanted to investigate their dose-response relationships in more detail. The scatter plots of IкB $\alpha$, STAT1, caspase 7, and cell death levels versus the AgNP uptake of monocytes and dendritic cells in Figures 5 and 6 confirm the previous observations about $\mathrm{I} \kappa \mathrm{B} \alpha$, STAT1, caspase 7, and cell death levels from Figures 1-4 in a single-cell dosedependent manner.

The dose-response relationships in monocytes and dendritic cells were similar. Through observation at single-cell resolution, we can see that the cellular uptake of 
${ }^{\mathrm{PVP}} \mathrm{Ag}^{20} \mathrm{NPs}$ was in fact slightly higher than that of ${ }^{\mathrm{PVP}} \mathrm{Ag}^{10} \mathrm{NPs}$, as there were more cells with over $10 \mathrm{fg}$ of $\mathrm{AgNP}$ uptake in the ${ }^{\mathrm{PVP}} \mathrm{Ag}^{20}$-treated sample than in the ${ }^{\mathrm{PVP}} \mathrm{Ag}^{10}$ treated sample. The degradation of I $\kappa \mathrm{B} \alpha$ and the phosphorylation of STAT1 were similarly dependent on cellular AgNP uptake, since IкB $\alpha$ and phospho-STAT1 levels were both inversely proportional to the AgNP uptake amounts. Cleaved caspase 7 levels in AgNP-treated samples was higher than that of the control but did not display clear dose-dependency. Unlike the other 3 markers mentioned above, cell death levels displayed a direct linear relationship with cellular AgNP uptake. This relationship maintained its linearity in the ${ }^{\mathrm{PVP}} \mathrm{Ag}^{10}$-treated samples (Figures 5,6B-D), as the cell death level increased accordingly with increases in cellular Ag dose, from mostly below $10 \mathrm{fg}$ (Figures 5,6B and 5,6C) to over $10 \mathrm{fg}$, and even reaching $100 \mathrm{fg}$ (Figures 5,6D). However, this linear relationship was not very consistent in the ${ }^{\mathrm{PVP}} \mathrm{Ag}^{20}$-treated samples (Figures 5,6E-G). In these samples, linearity was only maintained when the uptake amounts were below $10 \mathrm{fg}$. Above this threshold, the uptake amounts reached a plateau and did not increase any further.

\section{Discussion}

Mass cytometry allowed us to simultaneously analyze 21 markers to differentiate distinct populations of PBMCs and to examine their differential signaling expressions with high sensitivity and throughput in order to understand the immune response to nanomaterial exposure.

As silver NPs (AgNPs) have been increasingly used in consumer products and biomedical applications due to their antimicrobial properties, they have also been reported to enter the systemic circulation and exert toxicity on PBMCs, induce aggregation in platelets, and promote procoagulant activity in red blood cells (Greulich 
et al. 2011, Jun et al. 2011, Bian et al. 2019). When NPs come into contact with immune cells, they are often first taken up by the phagocytic cells (e.g. monocytes, macrophages, and dendritic cells) (Zolnik et al. 2010). However, internalization of NPs can also occur in other immune cells by lysosomal or endosomal endocytosis. The compatibility of NPs with the immune system is largely determined by their physicochemical properties, such as size and surface chemistry (Dobrovolskaia and McNeil 2007). When NPs are taken up by immune cells, there are several possibilities for how they will interact with one another: the first scenario is immune-mediated destruction or rejection, which could initiate a defensive immune reaction resulting in elimination of the NPs; the second is immunostimulation, which promotes inflammatory or autoimmune disorders; and the third is immunosuppression, which increases the host's susceptibility to infections (Luo et al. 2015). Oxidative stress and the release of metal ions have been reported as the two primary mechanisms that mediate the cytotoxicity of AgNPs (Völker et al. 2013). The acidic environment in lysosomeswhere AgNPs are abundantly accumulated—stimulates the intracellular release of metal ions. These ions and the cell-associated AgNPs may escape into the cytosol and subsequently cause oxidative stress via a ROS-dependent pathway. On the other hand, in a ROS-independent manner, $\mathrm{AgNPs}$ and the released $\mathrm{Ag}^{+}$ions may interact with the thiol groups of proteins, resulting in protein misfolding and eventually cell death (Riaz Ahmed et al. 2017). Metal ions have also been confirmed to mediate the toxicological pathways of metal-bearing NPs in a multiomics study that involved direct infusion mass spectrometry lipidomics, polar metabolomics, and RNA-sequencing transcriptomics (Dekkers et al. 2018). In this study, the majority of the molecular responses of human lung epithelial A549 cells to silver (Ag) and zinc oxide ( $\mathrm{ZnO}) \mathrm{NPs}$ - such as metallothionein induction, antioxidant depletion, repressed DNA repair, and apoptosis 
induction - are similar to their responses to $\mathrm{Ag}^{+}$and $\mathrm{Zn}^{2+}$ ions, respectively, confirming that the modes of action of these NPs are largely mediated by the corresponding dissolved metal ions.

Low concentrations ( 2 and $5 \mu \mathrm{g} / \mathrm{mL}$ ) of AgNPs were chosen for our experiments to avoid the saturation of silver intensity on the Helios platform and to maintain adequate cellular viability (Ivask et al. 2016), while still ensuring noticeable changes in cells' viability and signaling functions. Our results demonstrate that monocytes and dendritic cells had more affinity for AgNPs and were thus more vulnerable to their toxicity. From the cellular Ag content shown in the SPADE plots (Figure 1) and t-SNE plots (Figure 3), we can see that within 3 to $6 \mathrm{~h}$ of exposure, the cellular AgNP content in these cells was higher than in other populations. This cell-type-specific AgNP uptake can be explained by the intrinsic properties and functions of the cells. Monocytes and dendritic cells are partly adherent cells, so they can interact with both suspended and sedimented AgNPs in culture media. Furthermore, these cells belong to the cytic cell group, so they naturally tend to phagocytose the administered AgNPs (Luo et al. 2015). T cells and B cells, on the other hand, are non-adherent cells, so they can only interact with suspended AgNPs. Moreover, one of the functions of these cells is to generate cellular responses to remove foreign pathogens and particles (Luo et al. 2015), so they tend to eliminate AgNPs rather than phagocytose them.

Exposure to AgNPs led to activation of contrasting and complex cellular signaling pathways: STAT1 phosphorylation, IкB $\alpha$ degradation, and caspase 7 activation. I $\kappa \mathrm{B} \alpha$ is a molecule that can inhibit the anti-apoptotic NF- $\kappa \mathrm{B}$ transcription

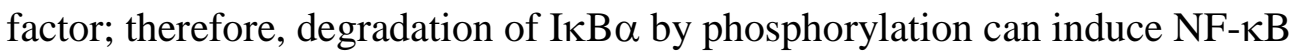
transcriptional activity and thus prevent apoptosis (Viatour et al. 2005). STAT1 is a 
transcription factor in the STAT protein family, which is a critical part of the JAKSTAT signaling pathway. Phosphorylation of STAT1 can prevent proliferation, promote inflammation, and induce apoptosis (Schindler et al. 2007). Caspase 7 belongs to the apoptosis executioner protein family, which is activated through proteolytic processing at conserved aspartic residues by upstream enzymes, including caspase 3,6,8, and 9, along with granzyme B. Upon activation, it will cleave downstream substrates and eventually lead to apoptosis (Lamkanfi and Kanneganti 2010). The contrasting expression patterns of the aforementioned pathways reflect the cells' efforts to achieve a more balanced response to the toxic effects of AgNP exposure.

The differences in phosphoprotein signaling and viability between cells treated with $2 \mu \mathrm{g} / \mathrm{mL}$ and those treated with $5 \mu \mathrm{g} / \mathrm{mL}$ of AgNPs were caused by the difference in administered dose. However, due to the nature of each cell type (as discussed earlier) and the colloidal behaviors of AgNPs in culture media (Ha et al. 2018), individual cells within one sample may associate with different numbers of AgNPs and express different levels of cellular responses. The scatter plots of I $\mathrm{B} \alpha$, STAT1, caspase 7, and cell death levels versus the AgNP uptake of monocytes and dendritic cells (Figures 5 and 6) confirm cell-to-cell variance in AgNP uptake and, consequently, in signaling

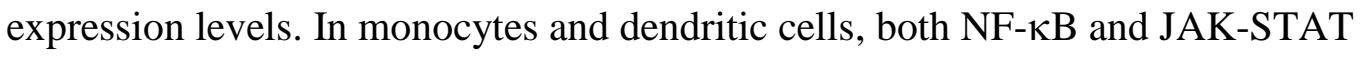
pathways were activated (via degradation of $\mathrm{I} \kappa \mathrm{B} \alpha$ and phosphorylation of STAT1, respectively) due to the induction of pro-inflammatory and pro-apoptotic signaling as the cellular Ag dose increased. Cell death levels, however, exhibited a direct linear relationship with cellular AgNP uptake. This relationship maintained its linearity in the ${ }^{\mathrm{PVP}} \mathrm{Ag}^{10}$-treated samples (Figure 5,6B-D), as the cell death level rose accordingly with the incremental increases in cellular Ag dose, from mostly below $10 \mathrm{fg}$ (Figures 5,6B and 5,6C) to over $10 \mathrm{fg}$, even reaching $100 \mathrm{fg}$ (Figures 5,6D). In addition, caspase 7 
cleavage in these samples remained steady regardless of increases in AgNP uptake amounts. This suggests that apoptosis occurred at medium cellular Ag doses (in this case, below $10 \mathrm{fg}$ ) and led to cell death at high cellular Ag doses (above $10 \mathrm{fg}$ ). On the other hand, the linear relationship between cell death level and AgNP uptake amounts was not very consistent in the ${ }^{\mathrm{PVP}} \mathrm{Ag}^{20}$-treated samples (Figure 5,6E-G). In this group, the linearity was only maintained when the uptake amounts were below $10 \mathrm{fg}$. Above this threshold, the uptake amounts remained steady regardless of increases in AgNP uptake. Caspase 7 cleavage in these samples slightly decreased when the cellular Ag dose exceeded $10 \mathrm{fg}$. This may indicate that above a cellular Ag dose of $10 \mathrm{fg}$, the phagocytic activities of monocytes and dendritic cells became more efficient and impeded apoptosis signaling, which in turn prevented a rise in cell death level. Similar observations were also reported in other publications, in which apoptosis occurred at a medium cellular dose of quantum dots (QDs), but was impeded by the particle-digestion of cells via autophagy at a higher cellular QD dose, leading to a partial recovery in cell viability at higher doses (Luo et al. 2013, Manshian et al. 2015). This observation may imply a size-dependent toxicity between the two AgNPs. Because the cell death level of monocytes treated with ${ }^{\mathrm{PVP}} \mathrm{Ag}^{10} \mathrm{NPs}$ still had the potential to rise when the cellular $\mathrm{Ag}$ content continued to increase, ${ }^{\mathrm{PVP}} \mathrm{Ag}^{10} \mathrm{NPs}$ should have higher toxicity than ${ }^{\mathrm{PVP}} \mathrm{Ag}^{20} \mathrm{NPs}$, whose cellular content above $10 \mathrm{fg}$ in mass did not cause an increase in cell death. Such heterogeneous cellular behaviors to subtoxic doses of AgNPs would have gone unnoticed had the response of the larger cell population simply been averaged.

\section{Conclusion}

In this study, we have adapted mass cytometry to investigate the cellular association and cytotoxicity mechanisms of 10 and $20 \mathrm{~nm}$ AgNPs in primary human immune cells. 
Thanks to the high sensitivity of this novel cytometry technique, we could observe the effects of these small AgNPs under non-toxic conditions with low doses (2 and $5 \mu \mathrm{g} / \mathrm{mL})$ and short exposure time ( 3 and $6 \mathrm{~h}$ ). High dimensionality of mass cytometry data allowed us to study the cellular association, cytotoxicity and cell death mechanisms of AgNPs in the heterogeneous immune cell populations. Our results showed that AgNPs were more likely to associate with phagocytic cells like monocytes and dendritic cells, and caused acute toxic effects, but had low affinity to adaptive immune cells such as T cells and B cells, and only caused minor toxicity. In addition to the heterogeneity in associating with different immune cell populations, there was also a great variance between individual cells of each cell type population. Multi-element detection capability of time-of-flight mass cytometry enabled us to quantitatively measure the cellular dose of AgNPs as well as cellular responses simultaneously, so that we could examine the dose-response relationship of cellular AgNPs with cell viability and signaling activities at a single-cell level. We have found that the cell death levels of monocytes and dendritic cells had a linear relationship with the amount of cellular AgNPs. In order to maintain their homeostasis upon the stimuli of AgNPs, monocytes and dendritic cells showed contrasting and complex signaling activities, such as STAT1 phosphorylation to promote inflammation, $\mathrm{NF}-\kappa \mathrm{B}$ signaling (via degradation of $\mathrm{I} \kappa \mathrm{B} \alpha$ ) to prevent apoptosis and caspase 7 activation to cleave downstream substrates that can eventually lead to apoptosis. These observations suggest that mass cytometry can reveal important information on the interactions between biological cells and NPs, such as heterogeneous association of NPs with different immune cell types, and single-cell level dose-response relationships for cell viability and other signaling activities, which are often hidden in traditional assays at bulk-cell level. We also think that our study will benefit development of single-cell level dose-response models for various NPs and will provide 
key information for the safe use of nanomaterials for biomedical applications.

\section{Acknowledgements}

Blood samples used in this study were obtained from Hanyang University Hospital (Seoul, Republic of Korea) with the approval of the Institutional Review Board (No. HYUH 2018-09005-004). Mass cytometry experiments were performed on the Helios CyTOF instrument at the Biotechnology Research Center in POSTECH, Republic of Korea. The authors would like to thank Prof. Young Tae Chang and Dr. Jong Jin Kim (Department of Chemistry, POSTECH, Republic of Korea) for providing access to the CyTOF instrument and helping with its operation. The authors also would like to appreciate Prof. Incheol Shin for his comments on this manuscript.

\section{Funding}

This project has received funding from the Bio \& Medical Technology Development Program of the National Research Foundation (NRF) supported by the Ministry of Science \& ICT under grant agreement No. 2017M3A9G8084539.

\section{Author contributions}

T.H.Y. designed and supervised research. K.M.H., Z.G., Y. L., Y.-E.K. and J. S. prepared samples. K.M.H. and S.J.K. performed the mass cytometry experiment. K.M.H. and J.S.C. performed data analysis. K.M.H. and T.H.Y. wrote the manuscript.

\section{Disclosure statement}

No potential conflict of interest was reported by the authors.

\section{Data availability}

All the data supporting the findings of this study are available from the corresponding author upon reasonable request.

\section{References}

AshaRani, P. V., Low Kah Mun, G., Hande, M.P., and Valiyaveettil, S., 2009.

Cytotoxicity and Genotoxicity of Silver Nanoparticles in Human Cells. ACS Nano, 3 (2), 279-290. 
Bandura, D.R., Baranov, V.I., Ornatsky, O.I., Antonov, A., Kinach, R., Lou, X., Pavlov, S., Vorobiev, S., Dick, J.E., and Tanner, S.D., 2009. Mass Cytometry: Technique for Real Time Single Cell Multitarget Immunoassay Based on Inductively Coupled Plasma Time-of-Flight Mass Spectrometry. Analytical Chemistry, 81 (16), 68136822.

Bendall, S.C., Simonds, E.F., Qiu, P., Amir, E.D., Krutzik, P.O., Finck, R., Bruggner, R. V., Melamed, R., Trejo, A., Ornatsky, O.I., Balderas, R.S., Plevritis, S.K., Sachs, K., Peter, D., Tanner, S.D., and Nolan, G.P., 2011. Single-Cell Mass Cytometry of Differential Immune and Drug Responses Across a Human Hematopoietic Continuum. Science, 332 (6030), 687-696.

Bian, Y., Kim, K., Ngo, T., Kim, I., Bae, O.-N., Lim, K.-M., and Chung, J.-H., 2019. Silver nanoparticles promote procoagulant activity of red blood cells: a potential risk of thrombosis in susceptible population. Particle and Fibre Toxicology, 16 (1), 9.

Colvin, V.L., 2003. The potential environmental impact of engineered nanomaterials. Nature Biotechnology, 21, 1166-1170.

Dekkers, S., Williams, T.D., Zhang, J., Zhou, J. (Albert), Vandebriel, R.J., De La Fonteyne, L.J.J., Gremmer, E.R., He, S., Guggenheim, E.J., Lynch, I., Cassee, F.R., De Jong, W.H., and Viant, M.R., 2018. Multi-omics approaches confirm metal ions mediate the main toxicological pathways of metal-bearing nanoparticles in lung epithelial A549 cells. Environmental Science: Nano, 5 (6), 1506-1517.

Dobrovolskaia, M.A. and McNeil, S.E., 2007. Immunological properties of engineered nanomaterials. Nature Nanotechnology, 2 (8), 469-478.

Ghosh, M., J, M., Sinha, S., Chakraborty, A., Mallick, S.K., Bandyopadhyay, M., and Mukherjee, A., 2012. In vitro and in vivo genotoxicity of silver nanoparticles. Mutation Research/Genetic Toxicology and Environmental Mutagenesis, 749 (12), 60-69.

Greulich, C., Diendorf, J., Geßmann, J., Simon, T., Habijan, T., Eggeler, G., Schildhauer, T.A., Epple, M., and Köller, M., 2011. Cell type-specific responses of peripheral blood mononuclear cells to silver nanoparticles. Acta Biomaterialia, 7 (9), 3505-3514. 
Guo, Y., Baumgart, S., Stärk, H.J., Harms, H., and Müller, S., 2017. Mass cytometry for detection of silver at the bacterial single cell level. Frontiers in Microbiology, 8, 1326.

Ha, M.K., Shim, Y.J., and Yoon, T.H., 2018. Effects of agglomeration on in vitro dosimetry and cellular association of silver nanoparticles. Environmental Science: Nano, 5 (2), 446-455.

Ivask, A., ElBadawy, A., Kaweeteerawat, C., Boren, D., Fischer, H., Ji, Z., Chang, C.H., Liu, R., Tolaymat, T., Telesca, D., Zink, J.I., Cohen, Y., Holden, P.A., and Godwin, H.A., 2014. Toxicity Mechanisms in Escherichia coli Vary for Silver Nanoparticles and Differ from Ionic Silver. ACS Nano, 8 (1), 374-386.

Ivask, A., Mitchell, A.J., Hope, C.M., Barry, S.C., Lombi, E., and Voelcker, N.H., 2017. Single Cell Level Quantification of Nanoparticle-Cell Interactions Using Mass Cytometry. Analytical Chemistry, 89 (16), 8228-8232.

Ivask, A., Mitchell, A.J., Malysheva, A., Voelcker, N.H., and Lombi, E., 2017. Methodologies and approaches for the analysis of cell-nanoparticle interactions. Wiley Interdisciplinary Reviews: Nanomedicine and Nanobiotechnology, e1486.

Ivask, A., Visnapuu, M., Vallotton, P., Marzouk, E.R., Lombi, E., and Voelcker, N.H., 2016. Quantitative multimodal analyses of silver nanoparticle-cell interactions: Implications for cytotoxicity. NanoImpact, 1, 29-38.

Jun, E.-A., Lim, K.-M., Kim, K., Bae, O.-N., Noh, J.-Y., Chung, K.-H., and Chung, J.H., 2011. Silver nanoparticles enhance thrombus formation through increased platelet aggregation and procoagulant activity. Nanotoxicology, 5 (2), 157-167.

Lamkanfi, M. and Kanneganti, T.D., 2010. Caspase-7: A protease involved in apoptosis and inflammation. The International Journal of Biochemistry \& Cell Biology, 42 (1), 21-24.

Luo, Y.-H., Wu, S.-B., Wei, Y.-H., Chen, Y.-C., Tsai, M.-H., Ho, C.-C., Lin, S.-Y., Yang, C.-S., and Lin, P., 2013. Cadmium-Based Quantum Dot Induced Autophagy Formation for Cell Survival via Oxidative Stress. Chemical Research in Toxicology, 26 (5), 662-673.

Luo, Y.H., Chang, L.W., and Lin, P., 2015. Metal-Based Nanoparticles and the Immune System: Activation, Inflammation, and Potential Applications. BioMed research 
international, 2015, 143720.

Van Der Maaten, L. and Hinton, G., 2008. Visualizing Data using t-SNE. Journal of Machine Learning Research, 9, 2579-2605.

Manshian, B.B., Munck, S., Agostinis, P., Himmelreich, U., and Soenen, S.J., 2015. High content analysis at single cell level identifies different cellular responses dependent on nanomaterial concentrations. Scientific Reports, 5 (1), 13890.

Martínez-Gutierrez, F., Thi, E.P., Silverman, J.M., de Oliveira, C.C., Svensson, S.L., Hoek, A. Vanden, Sánchez, E.M., Reiner, N.E., Gaynor, E.C., Pryzdial, E.L.G., Conway, E.M., Orrantia, E., Ruiz, F., Av-Gay, Y., and Bach, H., 2012.

Antibacterial activity, inflammatory response, coagulation and cytotoxicity effects of silver nanoparticles. Nanomedicine: Nanotechnology, Biology and Medicine, 8 (3), 328-336.

Merrifield, R.C., Stephan, C., and Lead, J.R., 2018. Quantification of Au Nanoparticle Biouptake and Distribution to Freshwater Algae Using Single Cell - ICP-MS. Environmental Science \& Technology, 52 (4), 2271-2277.

Meyer, S., López-Serrano, A., Mitze, H., Jakubowski, N., and Schwerdtle, T., 2018. Single-cell analysis by ICP-MS/MS as a fast tool for cellular bioavailability studies of arsenite. Metallomics, 10 (1), 73-76.

Nel, A., Xia, T., Mädler, L., and Li, N., 2006. Toxic Potential of Materials at the Nanolevel. Science, 311 (5761), 622-627.

Nemmar, A., Hoet, P.H.M., Vanquickenborne, B., Dinsdale, D., Thomeer, M., Hoylaerts, M.F., Vanbilloen, H., Mortelmans, L., and Nemery, B., 2002. Passage of Inhaled Particles Into the Blood Circulation in Humans. Circulation, 105 (4), $411-414$.

Orecchioni, M., Bedognetti, D., Newman, L., Fuoco, C., Spada, F., Hendrickx, W., Marincola, F.M., Sgarrella, F., Rodrigues, A.F., Ménard-Moyon, C., Cesareni, G., Kostarelos, K., Bianco, A., and G Delogu, L., 2017. Single-cell mass cytometry and transcriptome profiling reveal the impact of graphene on human immune cells. Nature Communications, 8 (1).

Park, J., Ha, M.K., Yang, N., and Yoon, T.H., 2017. Flow Cytometry-Based Quantification of Cellular Au Nanoparticles. Analytical Chemistry, 89 (4), 2449- 
2456.

Ray, P.C., Yu, H., and Fu, P.P., 2009. Toxicity and Environmental Risks of Nanomaterials: Challenges and Future Needs. Journal of Environmental Science and Health, Part C, 27 (1), 1-35.

Riaz Ahmed, K.B., Nagy, A.M., Brown, R.P., Zhang, Q., Malghan, S.G., and Goering, P.L., 2017. Silver nanoparticles: Significance of physicochemical properties and assay interference on the interpretation of in vitro cytotoxicity studies. Toxicology in Vitro, 38, 179-192.

Schindler, C., Levy, D.E., and Decker, T., 2007. JAK-STAT Signaling: From Interferons to Cytokines. Journal of Biological Chemistry, 282 (28), 20059-20063.

Singh, S., Carpenter, A.E., and Genovesio, A., 2014. Increasing the Content of HighContent Screening: An Overview. Journal of Biomolecular Screening, 19 (5), 640650.

Takenaka, S., Karg, E., Roth, C., Schulz, H., Ziesenis, A., Heinzmann, U., Schramel, P., and Heyder, J., 2001. Pulmonary and systemic distribution of inhaled ultrafine silver particles in rats. Environmental Health Perspectives, 109 (suppl 4), 547-551.

Tricot, S., Meyrand, M., Sammicheli, C., Elhmouzi Younes, J., Corneau, A., Bertholet, S., Malissen, M., Le Grand, R., Nuti, S., Luche, H., and Cosma, A., 2015. Evaluating the efficiency of isotope transmission for improved panel design and a comparison of the detection sensitivities of mass cytometer instruments. Cytometry Part A, 87 (4), 357-368.

Vanhecke, D., Rodriguez-Lorenzo, L., D. Clift, M.J., Blank, F., Petri-Fink, A., and Rothen-Rutishauser, B., 2014. Quantification of nanoparticles at the single-cell level: an overview about state-of-the-art techniques and their limitations. Nanomedicine, 9 (12), 1885-1900.

Viatour, P., Merville, M.-P., Bours, V., and Chariot, A., 2005. Phosphorylation of NF$\kappa \mathrm{B}$ and IкB proteins: implications in cancer and inflammation. Trends in Biochemical Sciences, 30 (1), 43-52.

Völker, C., Oetken, M., and Oehlmann, J., 2013. The Biological Effects and Possible Modes of Action of Nanosilver. In: D.M. Whitacre, ed. Reviews of Environmental Contamination and Toxicology Volume 223. New York, NY: Springer New York, 
81-106.

Wei, L., Lu, J., Xu, H., Patel, A., Chen, Z.-S., and Chen, G., 2015. Silver nanoparticles: synthesis, properties, and therapeutic applications. Drug Discovery Today, 20 (5), $595-601$.

Yang, Y.S., Atukorale, P.U., Moynihan, K.D., Bekdemir, A., Rakhra, K., Tang, L., Stellacci, F., and Irvine, D.J., 2017. High-throughput quantitation of inorganic nanoparticle biodistribution at the single-cell level using mass cytometry. Nature communications, 8, 14069.

Zolnik, B.S., González-Fernández, Á., Sadrieh, N., and Dobrovolskaia, M.A., 2010. Nanoparticles and the Immune System. Endocrinology, 151 (2), 458-465. 
Table 1. List of antibodies in the labeling panel.

\begin{tabular}{|c|c|c|c|c|c|}
\hline \multicolumn{6}{|c|}{ Surface antibodies } \\
\hline Target & Clone & Metal & Target & Clone & Metal \\
\hline CD11a & HI111 & ${ }^{142} \mathrm{Nd}$ & CD197 (CCR7) & G043H7 & ${ }^{159} \mathrm{~Tb}$ \\
\hline CD4 & RPA-T4 & ${ }^{145} \mathrm{Nd}$ & CD45RO & UCHL1 & ${ }^{165} \mathrm{Ho}$ \\
\hline CD8a & RPA-T8 & ${ }^{146} \mathrm{Nd}$ & CD44 & BJ18 & ${ }^{166} \mathrm{Er}$ \\
\hline CD16 & $3 \mathrm{G8}$ & ${ }^{148} \mathrm{Nd}$ & CD45RA & HI100 & ${ }^{169} \mathrm{Tm}$ \\
\hline CD7 & CD7-6B7 & ${ }^{147} \mathrm{Sm}$ & CD3 & UCHT1 & ${ }^{170} \mathrm{Er}$ \\
\hline CD45 & $\mathrm{HI} 30$ & ${ }^{154} \mathrm{Sm}$ & HLA-DR & L243 & ${ }^{174} \mathrm{Yb}$ \\
\hline \multicolumn{6}{|c|}{ Intracellular protein antibodies } \\
\hline Target & Clone & Metal & Target & Clone & Metal \\
\hline pSTAT5 & 47 & ${ }^{150} \mathrm{Nd}$ & pBAD & $40 \mathrm{~A} 9$ & ${ }^{161} \mathrm{Dy}$ \\
\hline Caspase-7 & D6H1 & ${ }^{152} \mathrm{Sm}$ & $\mathrm{I} \kappa \mathrm{B} \alpha$ & L35A5 & ${ }^{164} \mathrm{Dy}$ \\
\hline pSTAT1 & 58D6 & ${ }^{153} \mathrm{Eu}$ & $\mathrm{pERK} 1 / 2$ & $\mathrm{D} 13.14 .4 \mathrm{E}$ & ${ }^{171} \mathrm{Yb}$ \\
\hline p38 & D3F6 & ${ }^{156} \mathrm{Gd}$ & pS6 & N7-548 & ${ }^{175} \mathrm{Lu}$ \\
\hline pSTAT3 & 4/P-Stat3 & ${ }^{158} \mathrm{Gd}$ & & & \\
\hline
\end{tabular}




\section{Figures}
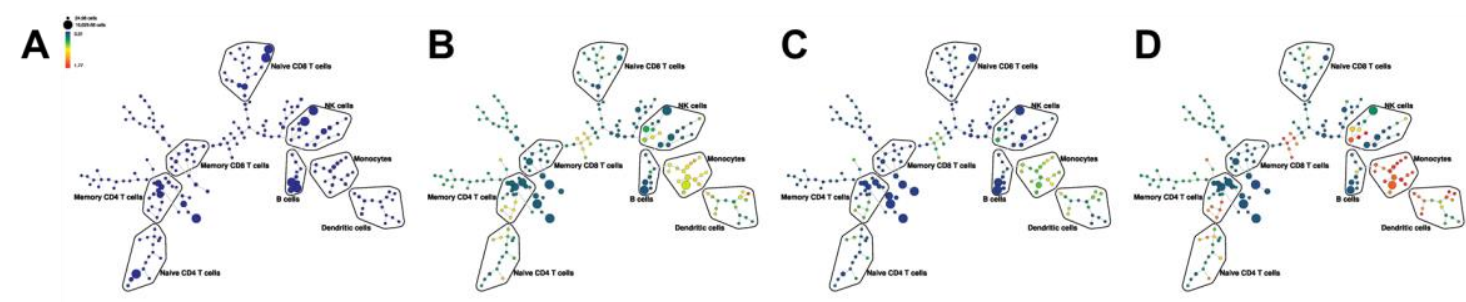

E

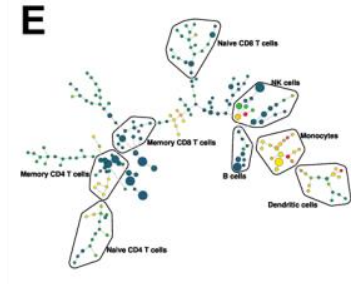

F

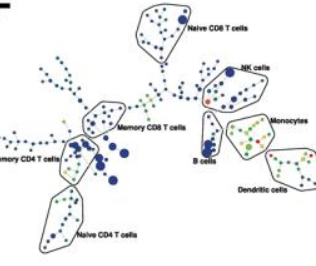

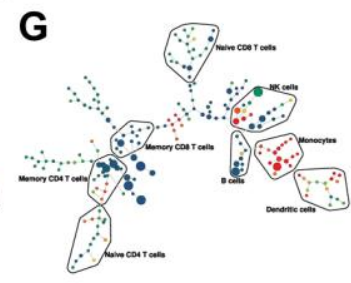

Figure 1.
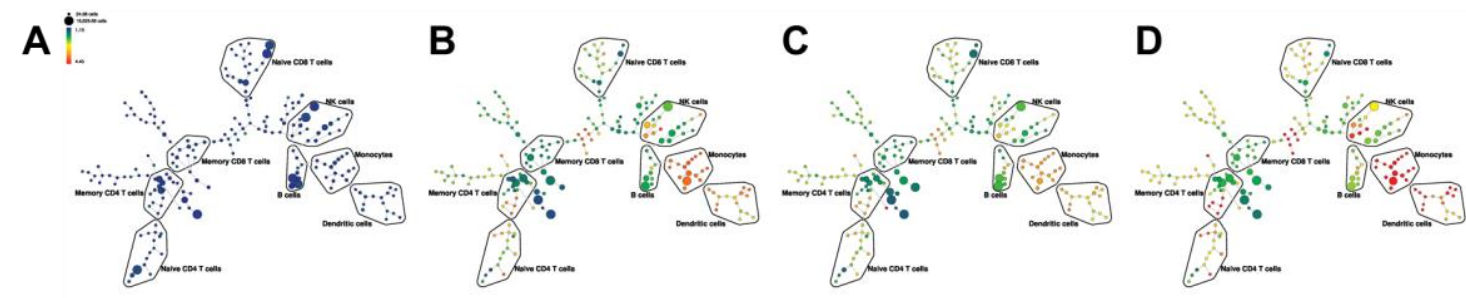

E

$\mathbf{F}$
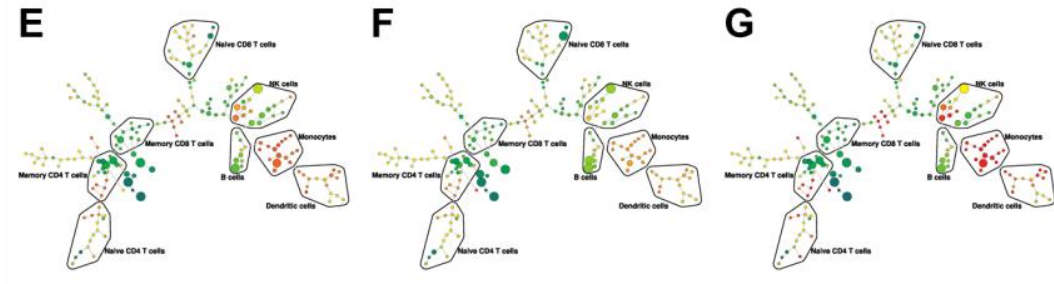

Figure 2. 


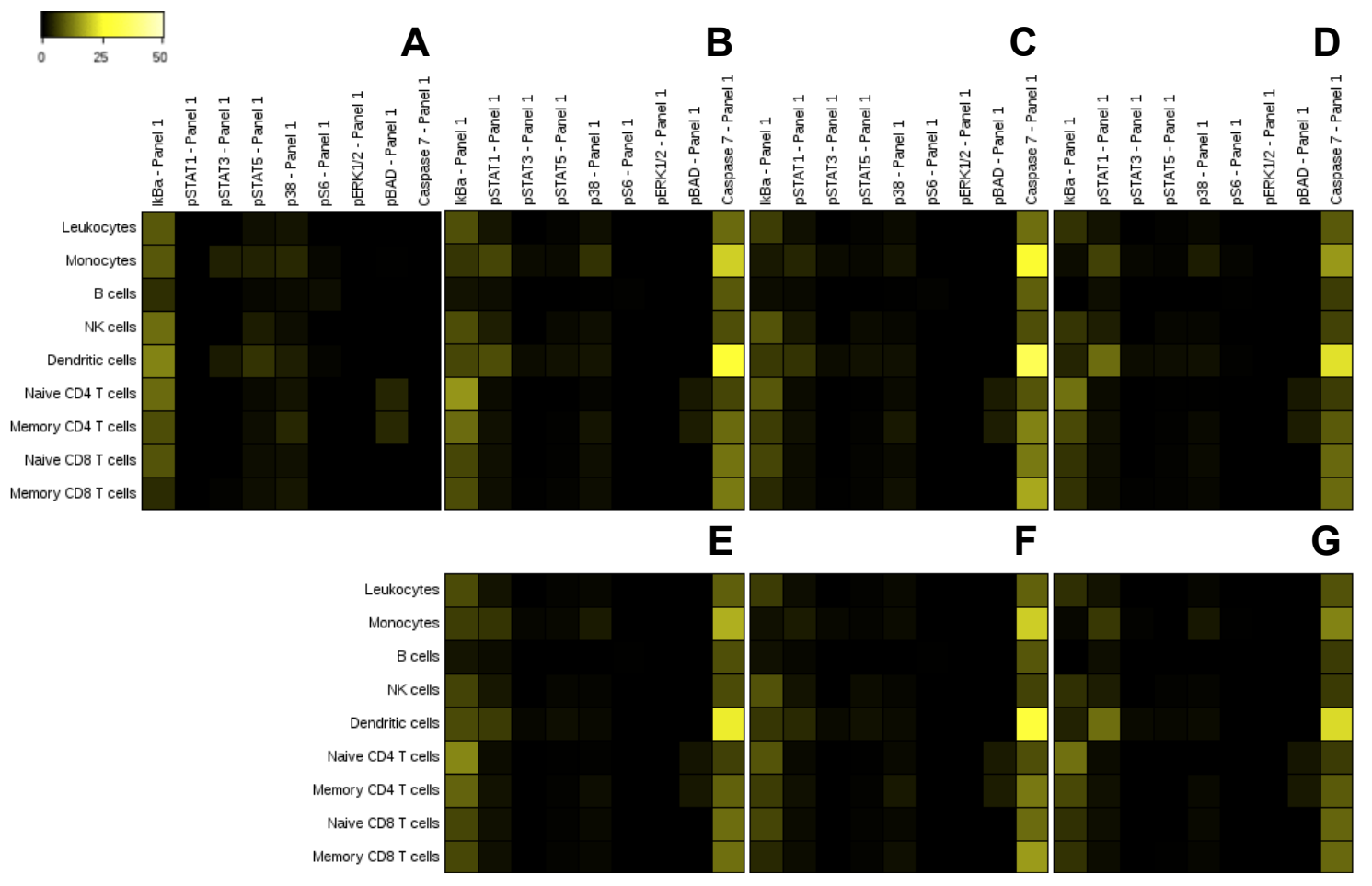

Figure 3. 
A

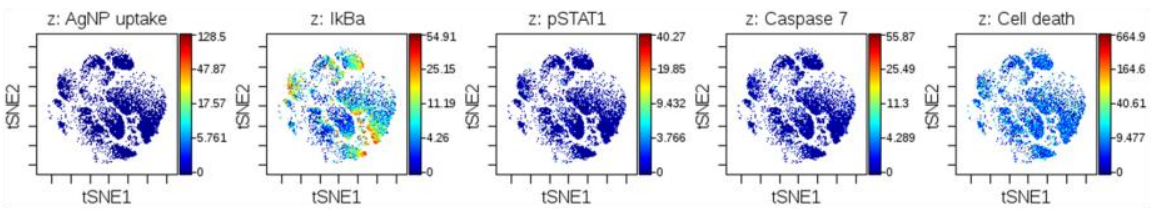

B

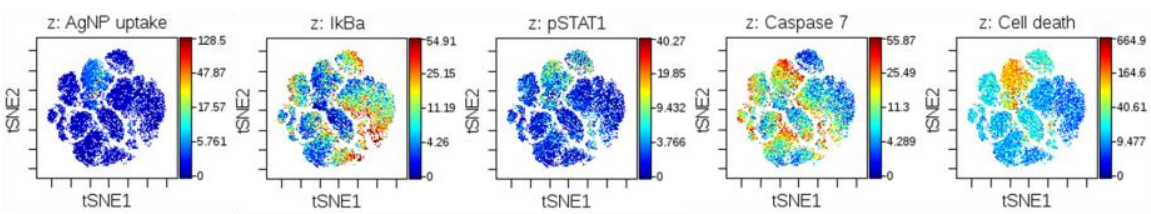

C

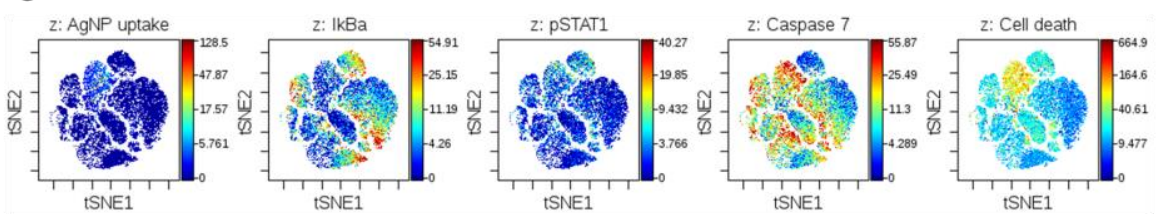

D

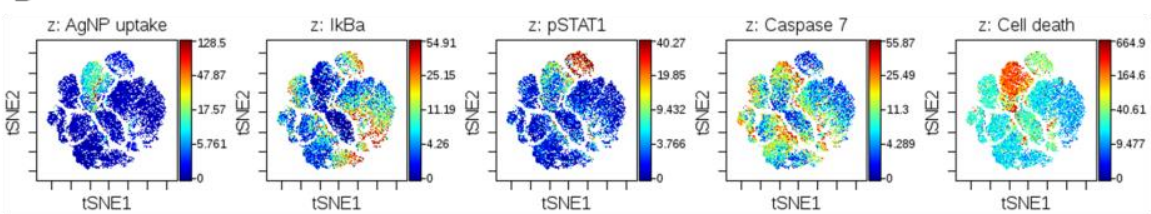

E

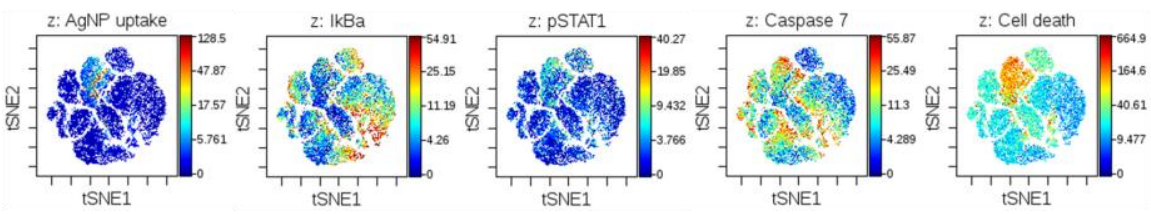

F

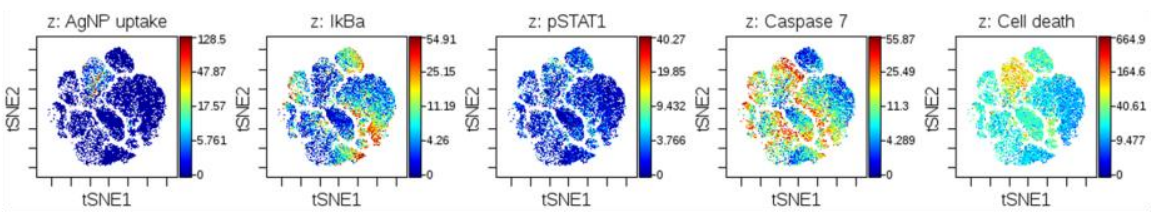

G
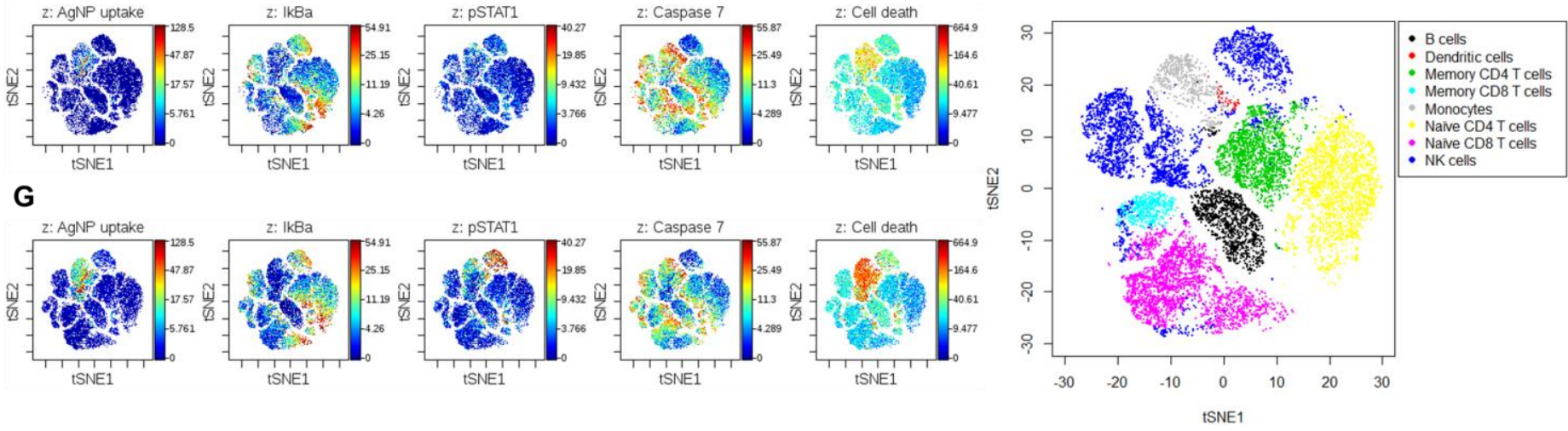

Figure 4. 


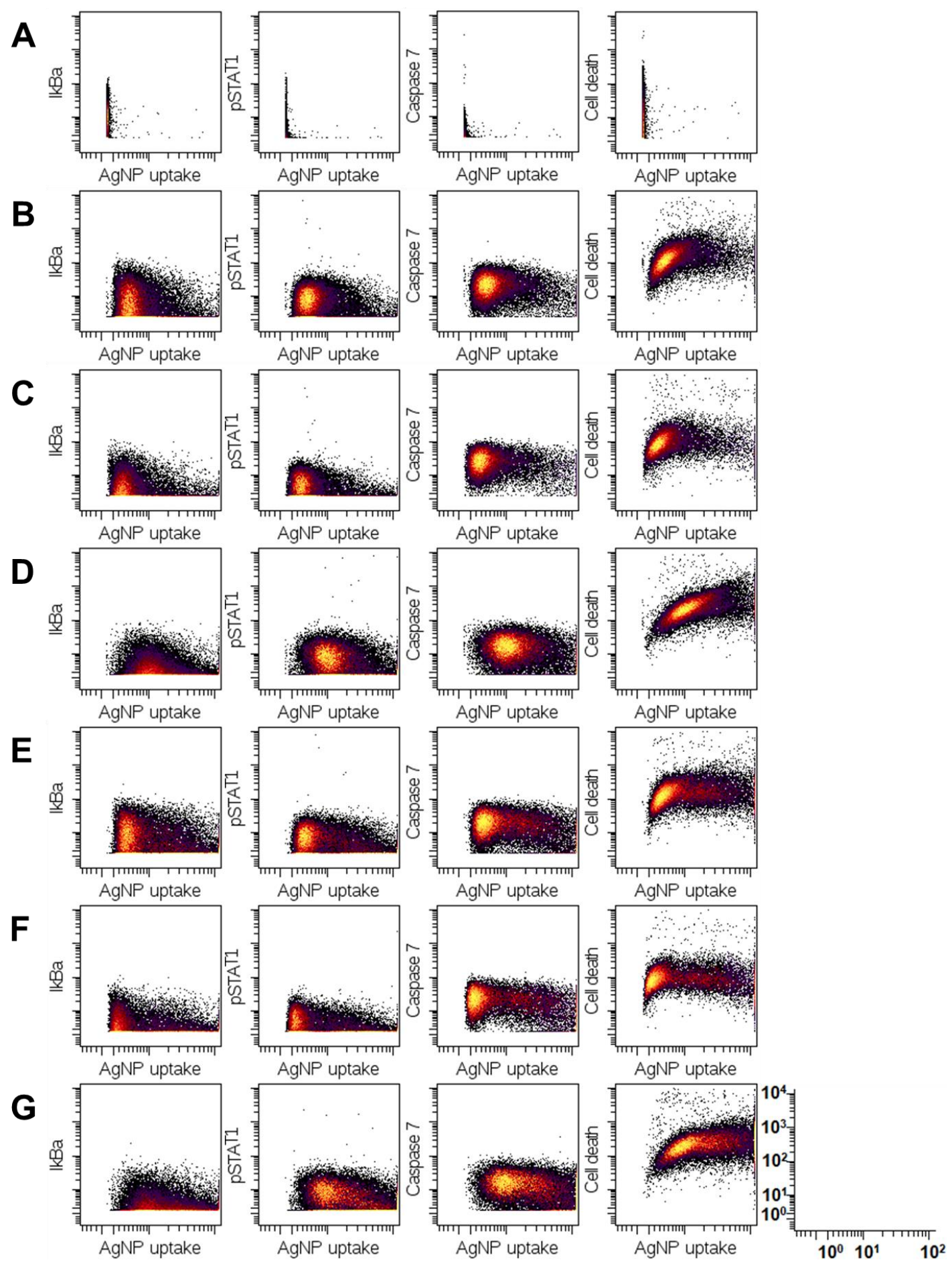

Figure 5. 


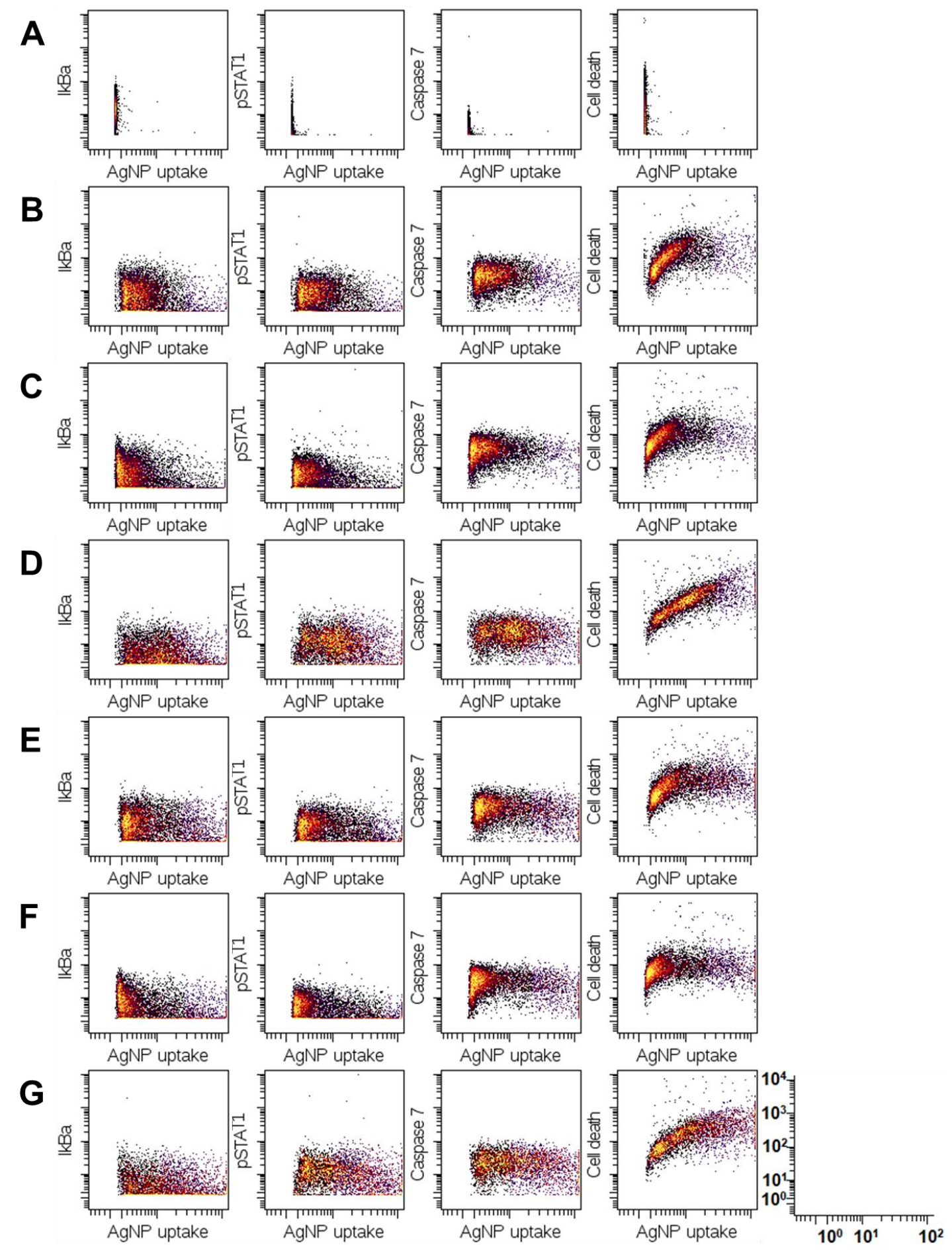

Figure 6. 


\section{Figure captions}

Figure 1. SPADE plots of cellular AgNP uptake in (A) control and (B-G) AgNP-treated samples. Exposure conditions were (B) ${ }^{\mathrm{PVP}} \mathrm{Ag}^{10} \mathrm{NPs}$ at $2 \mu \mathrm{g} / \mathrm{mL}$ for $3 \mathrm{~h},(\mathrm{C}){ }^{\mathrm{PVP}} \mathrm{Ag}^{10}$ NPs at $2 \mu \mathrm{g} / \mathrm{mL}$ for $6 \mathrm{~h}$, (D) ${ }^{\mathrm{PVP}} \mathrm{Ag}^{10} \mathrm{NPs}$ at $5 \mu \mathrm{g} / \mathrm{mL}$ for $3 \mathrm{~h}$, (E) ${ }^{\mathrm{PVP}} \mathrm{Ag}^{20} \mathrm{NPs}$ at $2 \mu \mathrm{g} / \mathrm{mL}$ for $3 \mathrm{~h},(\mathrm{~F}){ }^{\mathrm{PVP}} \mathrm{Ag}^{20} \mathrm{NPs}$ at $2 \mu \mathrm{g} / \mathrm{mL}$ for $6 \mathrm{~h}$, and $(\mathrm{G}){ }^{\mathrm{PVP}} \mathrm{Ag}^{20} \mathrm{NPs}$ at $5 \mu \mathrm{g} / \mathrm{mL}$ for $3 \mathrm{~h}$. Node color is scaled to the median mass of cell-associated Ag (in fg), with the lighter color (e.g. red) representing high intensity and the darker color (e.g. blue) representing low intensity.

Figure 2. SPADE plots of cell death in (A) control and (B-G) AgNP-treated samples. Exposure conditions were (B) ${ }^{\mathrm{PVP}} \mathrm{Ag}^{10} \mathrm{NPs}$ at $2 \mu \mathrm{g} / \mathrm{mL}$ for $3 \mathrm{~h},(\mathrm{C}){ }^{\mathrm{PVP}} \mathrm{Ag}^{10} \mathrm{NPs}$ at $2 \mu \mathrm{g} / \mathrm{mL}$ for $6 \mathrm{~h}$, (D) ${ }^{\mathrm{PVP}} \mathrm{Ag}^{10} \mathrm{NPs}$ at $5 \mu \mathrm{g} / \mathrm{mL}$ for $3 \mathrm{~h}$, (E) ${ }^{\mathrm{PVP}} \mathrm{Ag}^{20} \mathrm{NPs}$ at $2 \mu \mathrm{g} / \mathrm{mL}$ for $3 \mathrm{~h}$, (F) ${ }^{\mathrm{PVP}} \mathrm{Ag}^{20} \mathrm{NPs}$ at $2 \mu \mathrm{g} / \mathrm{mL}$ for $6 \mathrm{~h}$, and (G) ${ }^{\mathrm{PVP}} \mathrm{Ag}^{20} \mathrm{NPs}$ at $5 \mu \mathrm{g} / \mathrm{mL}$ for $3 \mathrm{~h}$. Node color is scaled to the median intensity of cisplatin expression, with the lighter color (e.g. red) representing high intensity and the darker color (e.g. blue) representing low intensity.

Figure 3. Heatmaps of phosphoprotein markers' expression levels in (A) control and (B-G) AgNP-treated samples. Exposure conditions were (B) ${ }^{\mathrm{PVP}} \mathrm{Ag}^{10} \mathrm{NPs}$ at $2 \mu \mathrm{g} / \mathrm{mL}$ for $3 \mathrm{~h},(\mathrm{C}){ }^{\mathrm{PVP}} \mathrm{Ag}^{10} \mathrm{NPs}$ at $2 \mu \mathrm{g} / \mathrm{mL}$ for $6 \mathrm{~h}$, (D) ${ }^{\mathrm{PVP}} \mathrm{Ag}^{10} \mathrm{NPs}$ at $5 \mu \mathrm{g} / \mathrm{mL}$ for $3 \mathrm{~h}$, (E) ${ }^{\mathrm{PVP}} \mathrm{Ag}^{20} \mathrm{NPs}$ at $2 \mu \mathrm{g} / \mathrm{mL}$ for $3 \mathrm{~h},(\mathrm{~F}){ }^{\mathrm{PVP}} \mathrm{Ag}^{20} \mathrm{NPs}$ at $2 \mu \mathrm{g} / \mathrm{mL}$ for $6 \mathrm{~h}$, and $(\mathrm{G}){ }^{\mathrm{PVP}} \mathrm{Ag}^{20}$ NPs at $5 \mu \mathrm{g} / \mathrm{mL}$ for $3 \mathrm{~h}$. The color scale indicates the median intensity of each marker.

Figure 4. t-SNE plots of cellular AgNP uptake (in fg) and I $\mathrm{B} \alpha$, STAT1, caspase 7, and cell death levels in (A) control and (B-G) AgNP-treated samples. Exposure conditions were (B) ${ }^{\mathrm{PVP}} \mathrm{Ag}^{10} \mathrm{NPs}$ at $2 \mu \mathrm{g} / \mathrm{mL}$ for $3 \mathrm{~h}$, (C) ${ }^{\mathrm{PVP}} \mathrm{Ag}^{10} \mathrm{NPs}$ at $2 \mu \mathrm{g} / \mathrm{mL}$ for $6 \mathrm{~h}$, (D) ${ }^{\mathrm{PVP}} \mathrm{Ag}^{10} \mathrm{NPs}$ at $5 \mu \mathrm{g} / \mathrm{mL}$ for $3 \mathrm{~h}$, (E) ${ }^{\mathrm{PVP}} \mathrm{Ag}^{20} \mathrm{NPs}$ at $2 \mu \mathrm{g} / \mathrm{mL}$ for $3 \mathrm{~h}$, (F) ${ }^{\mathrm{PVP}} \mathrm{Ag}^{20} \mathrm{NPs}$ at $2 \mu \mathrm{g} / \mathrm{mL}$ for $6 \mathrm{~h}$, and $(\mathrm{G}){ }^{\mathrm{PVP}} \mathrm{Ag}^{20} \mathrm{NPs}$ at $5 \mu \mathrm{g} / \mathrm{mL}$ for $3 \mathrm{~h}$. The color gradient represents the intensity of marker expression, in which the lighter color (e.g. red) shows high intensity and the darker color (e.g. blue) shows low intensity. Plot scale and cell type labeling are displayed at the bottom right corner.

Figure 5. Scatter plots of $\mathrm{I} \kappa \mathrm{B} \alpha$, STAT1, caspase 7, and cell death levels versus AgNP uptake (in fg) of monocytes in (A) control and (B-G) AgNP-treated samples. Exposure 
conditions were (B) ${ }^{\mathrm{PVP}} \mathrm{Ag}^{10} \mathrm{NPs}$ at $2 \mu \mathrm{g} / \mathrm{mL}$ for $3 \mathrm{~h}$, (C) ${ }^{\mathrm{PVP}} \mathrm{Ag}^{10} \mathrm{NPs}$ at $2 \mu \mathrm{g} / \mathrm{mL}$ for $6 \mathrm{~h}$, (D) ${ }^{\mathrm{PVP}} \mathrm{Ag}^{10} \mathrm{NPs}$ at $5 \mu \mathrm{g} / \mathrm{mL}$ for $3 \mathrm{~h}$, (E) ${ }^{\mathrm{PVP}} \mathrm{Ag}^{20} \mathrm{NPs}$ at $2 \mu \mathrm{g} / \mathrm{mL}$ for $3 \mathrm{~h}$, (F) ${ }^{\text {PVP }} \mathrm{Ag}^{20} \mathrm{NPs}$ at $2 \mu \mathrm{g} / \mathrm{mL}$ for $6 \mathrm{~h}$, and $(\mathrm{G}){ }^{\mathrm{PVP}} \mathrm{Ag}^{20} \mathrm{NPs}$ at $5 \mu \mathrm{g} / \mathrm{mL}$ for $3 \mathrm{~h}$. The color gradient represents cell density, in which the lighter color (e.g. yellow) shows high density and the darker color (e.g. black) shows low density. The scale is displayed at the bottom right corner.

Figure 6. Scatter plots of IкB $\alpha$, STAT1, caspase 7, and cell death levels versus AgNP uptake (in fg) of dendritic cells in (A) control and (B-G) AgNP-treated samples. Exposure conditions were (B) ${ }^{\mathrm{PVP}} \mathrm{Ag}^{10} \mathrm{NPs}$ at $2 \mu \mathrm{g} / \mathrm{mL}$ for $3 \mathrm{~h}$, (C) ${ }^{\mathrm{PVP}} \mathrm{Ag}^{10} \mathrm{NPs}$ at $2 \mu \mathrm{g} / \mathrm{mL}$ for $6 \mathrm{~h}$, (D) ${ }^{\mathrm{PVP}} \mathrm{Ag}^{10} \mathrm{NPs}$ at $5 \mu \mathrm{g} / \mathrm{mL}$ for $3 \mathrm{~h}$, (E) ${ }^{\mathrm{PVP}} \mathrm{Ag}^{20} \mathrm{NPs}$ at $2 \mu \mathrm{g} / \mathrm{mL}$ for $3 \mathrm{~h}$, (F) ${ }^{\mathrm{PVP}} \mathrm{Ag}^{20} \mathrm{NPs}$ at $2 \mu \mathrm{g} / \mathrm{mL}$ for $6 \mathrm{~h}$, and $(\mathrm{G}){ }^{\mathrm{PVP}} \mathrm{Ag}^{20} \mathrm{NPs}$ at $5 \mu \mathrm{g} / \mathrm{mL}$ for $3 \mathrm{~h}$. The color gradient represents cell density, in which the lighter color (e.g. yellow) shows high density and the darker color (e.g. black) shows low density. The scale is displayed at the bottom right corner. 